\title{
Characterization and Detection of Yellow Vein Disease of Okra (Abelmoschus esculentus (L.) Moench) in Sri Lanka
}

\author{
H.M.S.I. Senevirathna, S.K. Wasala ${ }^{1}$, D.M.J.B. Senanayake ${ }^{2}$, D. Weerasekara ${ }^{3}$ \\ H.A.M. Wickamasinghe ${ }^{4}$ and P.K.G.A. Deepal ${ }^{5}$
}
Post Graduate Institute of Agriculture, University of Peradeniya
Sri Lanka

\begin{abstract}
Begamoviruses transmitted by whitefly (Bemisia tabaci Genn, Family Aleyrodidae) cause severe damage to crop plants showing varying symptoms in different crop species. Okra Yellow Vein Mosaic Virus (OYVMV) is one of the most devastating diseases reported in okra cultivation worldwide. In this study, OYVMV disease severity and incidence of three recommended okra varieties were evaluated in field conditions at three different locations; Gannoruwa, Mahailuppalama and Angunakolapalasse. Similar disease symptoms were observed in Mahailuppallama and Angunakolapalasse. In Gannoruwa late infection caused lesser disease incidence and severity. Statistical analysis showed significant difference in severity and incidence of OYVMV among varieties as well as locations. MI 7 and MI 5 showed significantly high disease severity than $\underline{\text { Haritha }}$ while location Mahailluppallama showed significantly high disease severity followed by Angunakolapalasse. Diseased samples collected from these three locations and two additional locations i.e. Kilinochchi and Vauniya were subjected to PCR amplification with different begamovirus specific primers to identify the cross infection with other begamovirus diseases. All symptomatic samples collected from different locations showed positive results for OYVMV specific primer while none of the diseased samples showed positive results for Chili leaf curl virus, Tomato leaf curl virus, Okra leaf curl virus and Okra leaf curl crinkle virus disease specific primers. This study revealed that there is location and variety effect on OYVMV disease incidence and in these locations tested okra varieties were not cross infected with other tested viruses. Sequence analysis has to be done to identify genetic diversity of okra YVMV in different locations.
\end{abstract}

Keywords: Disease incidence, disease severity, okra yellow vein mosaic virus

\section{INTRODUCTION}

Okra, Abelmoschus esculentus (L.) Moench belongs to the family Malvaceae and is an important vegetable crop grown throughout the tropical and subtropical parts of the world. It provides an important source of vitamins, calcium, potassium and other minerals that are often lacking in diets of developing countries (IBPGR, 1990). Among the different species of

\footnotetext{
Plant Genetic Resources Centre, Department of Agriculture, Gannoruwa, Peradeniya,

Field Crop Research and Development Institute, Mahailuppallama

Grain Legume and Oil crop Research Centre, Angunakolapalasse

Faculty of Agriculture, University of Peradeniya

5 Faculty of Agriculture, Rajarata University of Sri Lanka

Corresponding author e-mail: samanthiwasala@yahoo.com
} 
genus Abelmoschus, the most popularly grown species is Abelmoschus esculentus in Asia and has a great commercial demand due to its nutritional value. The major production constraint for okra is okra Yellow vein mosaic virus (OYVMV) disease and it causes losses with regard to the quality as well as the yield wherever the crop is grown (Venkataravanappa et al., 2013). OYVMV was first reported from Mumbai in India (Kulkarni, 1924). This disease is transmitted through whitefly (Bemisia tabaci Genn, family Aleyrodidae). Okra plants infected by OYVMV show persistent symptoms of vein clearing followed by yellowing of whole leaf, reduction in leaf and fruit sizes and leading to a significant decrease of the produce. Based on the time of infection of the disease, up to $96 \%$ yield loss has been reported (Pun and Doraiswamy, 1999). Common begamovirus infecting plants shows similar symptoms in many crop species and different begomoviruses or strains differ with respect to their host range. The choice of crops by the whitefly may directly affect their prevalence in a particular region. During a mixed infection, whether two viruses will interact with each other synergistically or antagonistically, depends upon the host plant in which they are interacting (Mendez-Lozano et al., 2003). Plants usually offer resistance to geminiviruses through hypersensitive response (Mubin et al., 2010a; Hussain et al., 2005), and DNA- methylation (Raja, 2010; Raja et al, 2010) leading towards transcriptional gene silencing. Because of that, though the infection is there symptoms may not appear. Sattar, (2012) identified that okra in Africa is a host to many begomovirus complexes such as okra yellow crinkle virus and okra leaf curl cameroon virus. Further, strain differences of OYVMV were also identified by different research studies (Venkataravanappa et al, 2013). In 2015, Roy and co-workers observed alternate hosts of YVMV disease. Therefore, characterization and identification of okra infecting begamoviruses are important in crop improvement programmes.

In Sri Lanka, none of the recommended varieties showed consistent resistance to YVMV disease. Confirmation studies of OYVMV resistance in genotype of okra proved that the highly resistant genotypes possessed true and stable resistance reactions against this virus (Ali et al., 2005). Therefore, utilization of crop genetic resources to enhance the resistance in cultivated okra is one of the solutions to overcome this problem. Incidence and severity of OYVMV disease are affected by environmental conditions. Decrease in minimum temperature was conducive for disease development while increase in relative humidity (Ali et al., 2005) and high rainfall (Leite et al., 2005) was detrimental to whitefly population. The objectives of this study were to evaluate three recommended okra varieties against OYVMV in three different locations, and to confirm the presence of OYVMV by virus specific primers and to test for the presence of other whitefly-transmitted geminiviruses as mixed infections in okra.

\section{MATERIALS AND METHODS}

\section{Morphological characterization of yellow vein disease of okra}

The study was conducted at research fields of Plant Genetic Resource Centre (PGRC), Gannoruwa, Field Crop Research and Development Institute (FCRDI), Mahailuppallama and Grain Legume and Oil crop Research and Development Centre (GLORDC), Angunakolapalassa during Yala (April to July) 2014.

Three recommended okra varieties (MI5, MI7 and Haritha) were grown in the field with the plot size of $1.8 \mathrm{~m} \times 1.8 \mathrm{~m}$ in a randomized complete block design (RCBD) with three replicates. Plant spacing was $90 \mathrm{~cm} \times 90 \mathrm{~cm}$. All the cultural practices were done according to the recommendations of Department of Agriculture. YVMV disease pressure was increased 
by cultivating highly susceptible variety; MI-7 around the field as a boarder crop and natural infection was allowed. Disease symptoms and number of diseased plants were recorded 35, $45 \& 55$ days after planting. Disease severity was recorded according to the procedure given by Ali et al. (2005) with a slight modification. Table 1 summarizes the disease symptoms and respective severity scale used in this study. Based on that scale Percentage of Disease Incidence (PDI) (Sankara and Acharyya, 2012) and Disease Severity Index (DSI) (McKinney, 1923) were calculated.

Table 1. Description of OYVMV disease symptoms used for scoring

\begin{tabular}{|c|c|c|c|}
\hline Description of symptoms & $\begin{array}{c}\text { Severity } \\
\text { scale }\end{array}$ & $\begin{array}{c}\text { Rating } \\
\text { Scale }\end{array}$ & $\begin{array}{c}\text { Severity } \\
\text { Range }\end{array}$ \\
\hline Absence of symptoms & 0 & HR & $0 \%$ \\
\hline Very mild symptoms, initial vein clearing & 1 & $\mathrm{R}$ & $1-20 \%$ \\
\hline $\begin{array}{l}\text { Leaf veins completely yellow and inter-veinal } \\
\text { regions remain green or normal }\end{array}$ & 2 & MR & $20-40 \%$ \\
\hline Curly leaves and whole leaf get yellow color & 3 & MS & $40-60 \%$ \\
\hline $\begin{array}{l}\text { Whole leaf yellow coloured. Leaf Margin start } \\
\text { drying }\end{array}$ & 4 & S & $60-80 \%$ \\
\hline $\begin{array}{l}\text { Yellowish and deformed pods with whole leaf } \\
\text { yellow coloured. All leaves of the plant get } \\
\text { affected }\end{array}$ & 5 & HS & $80-100 \%$ \\
\hline
\end{tabular}

Adopted from: Ali et al., (2005)

Note: R - Resistant, HR - Highly resistant, MR - Moderately resistant, MS - Moderately susceptible, S -

Susceptible, HS - Highly Susceptible

$$
\text { PDI }=\frac{\text { Number of diseased plants }}{\text { Total Number of plants observed }} \times 100
$$

PDI= Percentage of Disease Incidence, (Sankara and Acharyya, 2012)

$$
\text { DSI }=\frac{\Sigma \text { Severity scale } \mathrm{x} \text { Total of infected plants }}{5 \times \text { Total number of plants }} \times 100
$$

DSI - Disease Severity Index (McKinney, 1923)

\section{Data analysis}

Data were transformed using Box-Cox transformation in Minitab (MINITAB 14) and Analysis of variance was done for transformed data of DSI. Mean separation was done to find out the location and variety differences according to the Tukey's Studentized Range test using Statistical Analysis System software (SAS, version 9.0). 


\section{RESULTS AND DISCUSSION}

\section{Morphological characterization of yellow vein disease of okra}

Okra plants of all three locations were infected with OYVMV disease. Mahailluppallama and Angunakolapelessa locations showed heavy infestation while plants grown in Gannoruwa showed the least virus infection. PDI and DSI of OYVMV disease in each variety at Mahailuppallama, Angunakolapalasse and Gannoruwa are shown in figure 1. The disease symptoms at Gannoruwa appeared 90 days after sowing where very mild symptoms were observed in both variety $M I 7$ and $M I 5$ while variety Haritha was not affected with OYVMV disease until the experiment period is over.

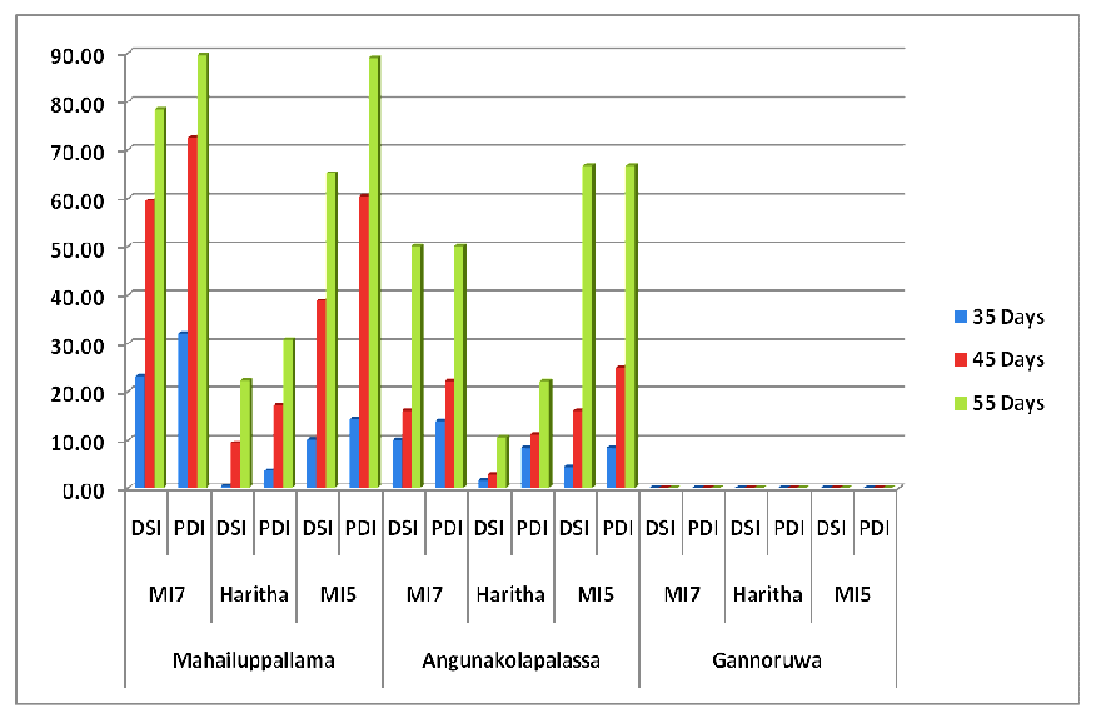

Fig. 1. Percentage of Disease Incidence (PDI) and Disease Severity Index (DSI) of three different okra varieties in Mahailuppallama, Angunakolapalasse and Gannoruwa

There was OYVMV infection at early stage of crops grown in Mahailuppallama and Angunakolapalasse in all three recommended varieties. The severity and disease incidence were increased at an increasing rate. With time the yield of these two locations was very poor when compared to the yield at Gannoruwa (data not shown). The rate of increase in disease incidence was more at the early stages rather than that at later stages of the plant growth at Mahailuppallama and Angunakolapalasse in all tested varieties. Severity of the disease is high in Mahailuppallama than that of the other two locations in all three varieties. Disease symptoms observed in Mahailuppallama include vein and vein-let chlorosis, whole lamina becoming uniformly crinkled and yellow with regularly distributed green tissue in the inter venial regions and finally totally yellowish colour leaf with dried leaf margins and pods were complete yellow colour. Disease symptoms first observed in MI 7 and then symptoms appeared in both upper and lower leaves of all three varieties. Symptoms observed in Angunakolapalasse were very much similar to the symptoms observed in Mahailuppallama such as vein and veinlet chlorosis, puckering of leaves, drying of leaf margins, yellowing of whole leaf. Deformed pods were also observed in these two locations. Two distinct vein clearing patterns were observed in Gannoruwa, one type was vein clearing occurred in 
mosaic pattern and the other type was mid vein turned into yellow colour without mosaic symptoms (Plate 1). In Mahailuppallama and Angunakolapalasse variety Haritha showed late infection and lesser severity than two other tested varieties while at Gannoruwa no symptoms were observed in variety Haritha. The different symptoms observed in different locations were showed in Plate 1.

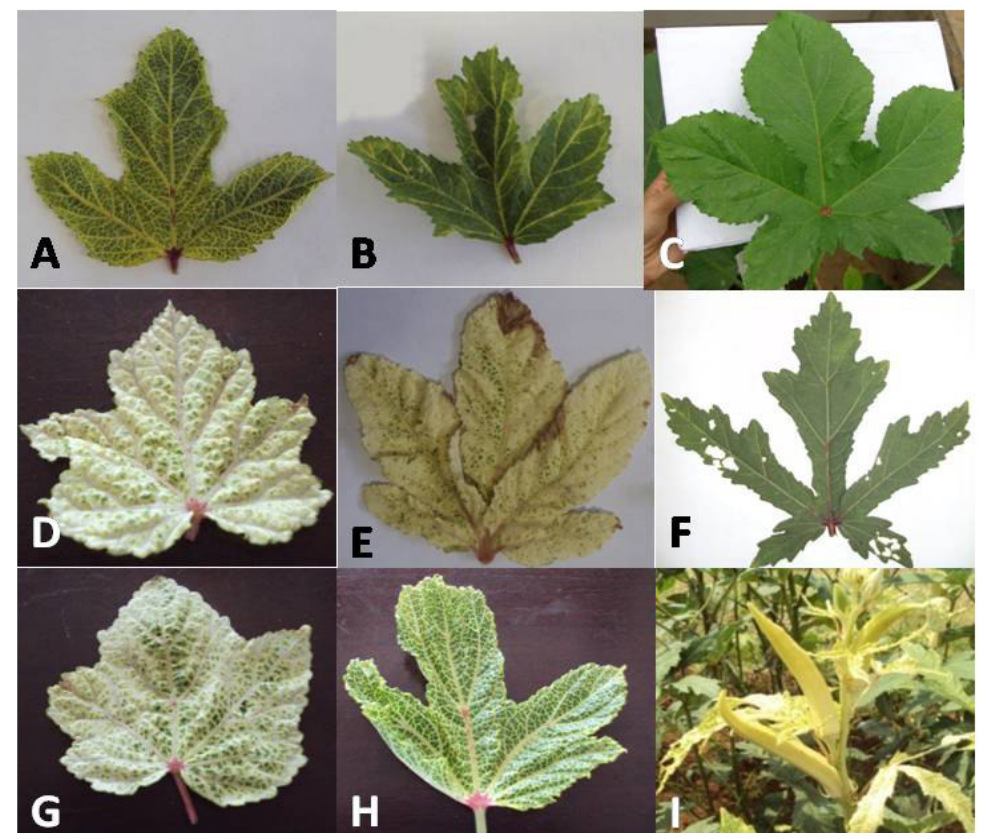

Plate 1. Different symptoms of OYVMV observed in different locations (A) vein clearing occurred in mosaic pattern (Gannoruwa). (B) Mid vein turned into yellow colour without mosaic symptoms (Gannoruwa). (C) Non-symptomatic leaf collected from Gannoruwa. (D) Diseased okra leaves collected from Mahailuppallama, (E) Diseased okra leaves collected from Angunakolapalasse. (F) Non-symptomatic leaf collected from Angunakolapalasse (variety Haritha at 70 days after planting), (G) Diseased okra leaves collected from Vauniya, (H) Diseased okra leaves collected from Kilinochchi, (I) Complete yellow colour pods observed in Mahailuppallama

Analysis of variance of transformed data of DSI showed that there is significant difference of variety and location on DSI. Location and variety are significant at probability levels of $\mathrm{p}=0.0231$ and $\mathrm{p}=0.006$ respectively, while there is no significant location $\mathrm{x}$ variety interaction on disease severity. Results of Tukey's Studentized Range test revealed that the disease severity of variety Haritha is significantly lower than variety MI 5 and MI 7 in all tested locations. Disease severity of location Mahailuppalama was significantly high followed by Angunakolapalasse. Significantly least disease severity was observed at Gannoruwa. 


\section{Molecular Confirmation of Yellow Vein Disease of Okra}

PCR products obtained with different primers were resolved in $1.5 \%$ agarose gel. Image of PCR products of okra YVMV primer, Tomato leaf curl virus primer and Chili leaf curl virus primer visualized under UV light in Gel documentation system is shown in Plate 2.
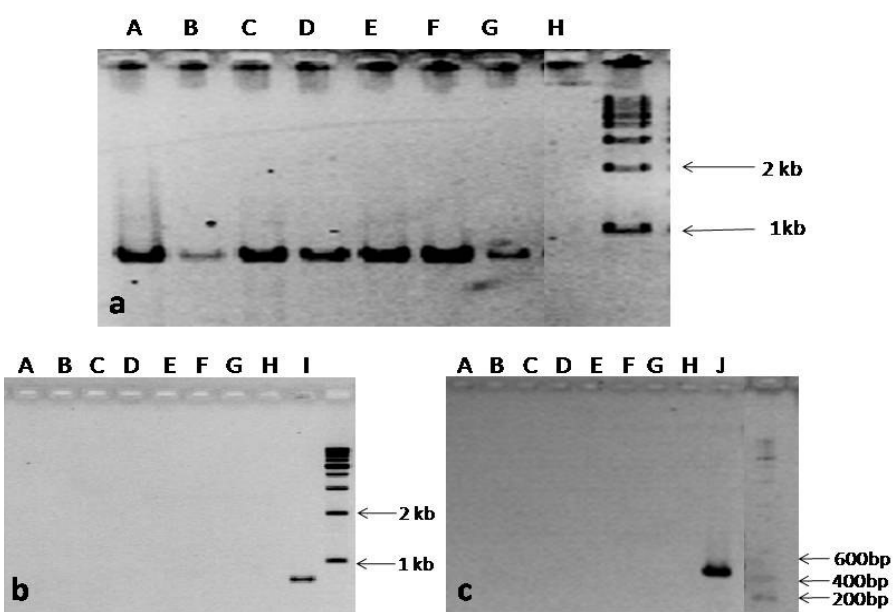

Plate 2. Amplified PCR products of different virus specific primers in $1.5 \%$ agarose gel for diseased okra samples collected from different locations, (a) OYVMV primer, (b) Tomato leaf curl virus primer and (c) Chili leaf curl virus primer, A- diseased leaf sample from Gannoruwa in which was vein clearing occurred in mosaic pattern, B- diseased leaves sample from Gannoruwa in which mid vein turned yellow colour without mosaic symptoms, C- Diseased okra leaf sample collected from Mahailuppalama, D -Diseased okra leaf sample collected from Angunakolapalasse. E- Diseased okra leaf sample collected from Kilinochchi, F- Diseased okra leaf sample collected from Vauniya, G - Nonsymptomatic leaf collected from Angunakolapalasse, H- Non-symptomatic leaf collected from Gannoruwa, I - Tomato leaf curl virus disease sample, J- Chili leaf curl virus disease sample

For OYVMV specific primer, all the tested samples from five locations gave corresponding fragment size of $800 \mathrm{bp}$ for OYVMV proves that all the diseased samples collected from the five locations are infected with OYVMV. Samples, which showed vein clearing without mosaic symptoms collected from Gannoruwa and Non-symptomatic samples collected from Angunakolapallasse gave a light band for OYVMV primer while non-symptomatic leaves collected from Gannoruwa did not produce any amplification. It revealed that YVMV disease can be latent in the plant without showing symptoms and disease specific primers could help to identify the disease. Chili leaf curl virus specific primer and tomato leaf curl virus specific primer did not give any amplification for infected okra samples. However, positive results were shown for both leaf curl virus infected chili and tomato samples. Okra leaf curl virus and Okra leaf curl crinkle virus primers did not give any amplification for any of the samples tested. It proves that none of the samples collected from different locations were cross infected with respective begamoviruses. 
According to the observations at different locations all three recommended varieties were infected by OYVMV to varying degree of intensities. None of the varieties evaluated were found to be resistant to OYVMV disease. The more susceptible responses have been observed in variety $M I 7$ and $M I 5$ in all three locations. Further, moderate resistant response was shown by variety Haritha. This may be due to inherent varietal character of Haritha. Presence of PCR amplicons in OYVMV primer for both symptomatic and non symptomatic samples revealed that there was infection with or without observable symptoms. Because molecular study showed that plants of variety Haritha has been infected with the disease though there was less symptom or no symptoms appear in field conditions. Direct expression of viral infectivity might be blocked at any of several stages of virus lifecycle. These blocks might be related to differences in biology of the host system (Ahlquist et al., 1984). In addition, plants also induce hypersensitive and systemic acquired resistance responses, which together limit the viral infection and impart resistance to the non infected tissues. Disease incidence of plants grown in Gannoruwa was observed more than 75 days after planting. Therefore, less yield damage was observed. This may be due to differential response of varieties to the environmental conditions. In 2012, Ali and co workers showed that there was a significant correlation between environment and disease severity of OYVMV disease in okra. In Gannoruwa minimum average temperature is less than the two other locations and the rainfall was high during the studied period (data not shown). Minimum temperature and relative humidity had significant correlations with YVMV disease severity and whitefly population (Ali et al., 2005). The disease incidence increased with the rise in minimum temperature and whitefly population decreased with increase in the relative humidity (RH) (Ali et al., 2005) and total rainfall (Leite et al., 2005). Therefore, variation in environmental conditions and its interaction could have affected to the differences in white fly population, then changing the disease incidence and severity at three locations.

\section{CONCLUSION}

All three recommended okra varieties used in the study were infected with OYVMV disease at varying degree of disease severity and there is a significant difference in variety and location on disease severity. None of the tested okra diseased samples were cross infected with Chili leaf curl virus, Tomato leaf curl virus, Okra leaf curl virus and Okra leaf curl crinkle viruses.

\section{ACKNOWLEDGEMENT}

This research was financially supported by the National Research Council, Sri Lanka. Authors wishes to thank Deputy Director, Plant Genetic Resources Centre, Director, Field Crops Research and Development Institute and Additional Director, Grain Legume \& Oil Crop Research and Development Centre, for providing facilities to conduct this research successfully.

\section{REFERENCES}

Ahlquist, P., French, R., Janda, M. and Loesch-Fries, L.S. (1984). Multicomponent RNA plant virus infection derived from cloned viral cDNA. Proceedings of the National Academy of Sciences. 81(22), 7066 - 7070. 
Ali, M., Khan, M., Rashid, A., Ehetisham-ul-haq, M., Javed. M. and Sajid, M. (2012). Epidemiology of Okra Yellow Vein Mosaic Virus (OYVMV) and Its Management through Tracer, Mycotal and Imidacloprid, American Journal of Plant Sciences. 3(12), 1741-1745.

Ali, S., Khan, M.A., Habib, A., Rasheed, S. and Iftikhar, Y. (2005). Correlation of Environmental Conditions with Okra Yellow Vein Mosaic Virus and Bemisia tabaci Population Density. International journal of agriculture \& biology. 7, 142-144.

Hussain, M., Mansoor, S., Iram, S., Fatima, A.N. and Zafar, Y. (2005). The nuclear shuttle protein of Tomato leaf curl New Delhi virus is a pathogenicity eterminant. Journal of Virology. 79, 4434 - 4439.

International Board for plant genetic resources IBPGR. (1990). Report on International Workshop on Okra Genetic Resources held at the National Bureau of plant Genetic Resources, New Delhi, India.

Kochko, A. and Hamon, S. (1990). A Rapid and Efficient Method for the Isolation of Restrictable Table DNA from Plants of the Genus Abelmoschus, Plant Mol. Bio. Repoter. 8, 3-7.

Kulkarni, G.S. (1924). Mosaic and other related diseases of crops in the Bombay presidency. Poona Agriculture College Magazine. 16, 6-12.

Leite, G.L.D., Picanço, M., Jham, G.N. and Moreira, M.D. (2005). Whitefly population dynamics in okra plantations. Pesq. agropec. Bras. Brasília. 40(1), 19-25. [on line]. [Accessed on 27.07.2015]. Available at http://www.scielo.br/scielo.php?script=sci_arttext\&pid=S0100204X2005000100003\&lng=e n\&tlng=en. 10.1590/S0100-204X2005000100003.

Mckinney, H.H. (1923). Influence of soil temperature and moisture on infection of wheat seedlings by Helminthosporium sativum. J. Agric. Res. 26, 195 - 217.

Mendez-Lozano, J., Torres-Pacheco, I., Fauquet, C.M. and Rivera-Bustamante, R. (2003). Interactions between geminiviruses in a naturally occurring mixture: Pepper huasteco virus and Pepper golden mosaic virus. Phytopathology. 93(3), 270 - 277.

Mubin, M., Amin, I., Amrao, L., Briddon, R.W. and Mansoor, S. (2010a). The hypersensitive response induced by the $\mathrm{V} 2$ protein of a monopartite egomovirus is countered by the C2 protein. Molecular Plant Pathology. 11(2), $245-254$.

Pun, K.B and Doraiswamy, S. (1999). Effect of age of okra plants on susceptibility to okra yellow vein mosaic virus. Indian J. Virol. 15, 57 - 58.

Raja, P. (2010). Methylation of Geminivirus Genomes: Investigating its role as a host defense and evaluating its efficacy as a model to study chromatin methylation in plants. Doctorial Dissertation. Ohio State University.

Raja, P., Wolf, J.N. and Bisaro, D.M. (2010). RNA silencing directed against geminiviruses: post-transcriptional and epigenetic components. Biochimica et Biophysica Acta. 1799(3-4), $337-351$. 
Roy, B., Chakraborty, B., Mitra, A., Sultana, S. and Sherpa, A.R. (2015). Natural occurrence of Bhendi yellow vein mosaic virus on Litsea spp. in India. New Disease Reports 31, 7. [on line]. [Accessed on 27.07.2015]. Available at http://dx.doi.org/10.5197/j.20440588.2015.031.007

Sankara, R.K. and Acharyya, P. (2012). Incidence of yellow vein mosaic virus disease of okra [Abelmoschus esculentus (L.) Moench] under summer and rainy environments. Int. J. Curr. Res. 4(5), $18-21$.

Sattar, M.N. (2012). Diversity and interactions of begomoviruses and their associated DNAsatellites. Doctorial thesis, Swedish University of Agricultural Sciences, Uppsala, Sweden.

Venkataravanappa, V., Lakshminarayana Reddy, C.N. and Krishna Reddy, M. (2013). Begomovirus characterization and development of phenotypic and DNA-based diagnostics for screening of okra genotype resistance against Bhendi yellow vein mosaic virus. 3 Biotech. 3(6), $461-470$. 